Man and Nature

L'homme et la nature

\title{
The Performing Arts and the Court of Louis XVI
}

\section{Paul F. Rice}

Volume 11, 1992

URI : https://id.erudit.org/iderudit/1012672ar

DOI : https://doi.org/10.7202/1012672ar

Aller au sommaire du numéro

Éditeur(s)

Canadian Society for Eighteenth-Century Studies / Société canadienne d'étude du dix-huitième siècle

ISSN

0824-3298 (imprimé)

1927-8810 (numérique)

Découvrir la revue

Citer cet article

Rice, P. F. (1992). The Performing Arts and the Court of Louis XVI. Man and Nature / L'homme et la nature, 11, 59-75. https://doi.org/10.7202/1012672ar

Copyright (c) Canadian Society for Eighteenth-Century Studies / Sociéte canadienne d'étude du dix-huitième siècle, 1992
Ce document est protégé par la loi sur le droit d'auteur. L'utilisation des services d'Érudit (y compris la reproduction) est assujettie à sa politique d'utilisation que vous pouvez consulter en ligne.

https://apropos.erudit.org/fr/usagers/politique-dutilisation/ 


\section{The Performing Arts and the Court of Louis XVI}

During the ancien régime, the court served as both artistic and political leader of the nation. It was Louis XIV who best understood the political value of the performing arts and, after 1661, began a concerted effort to organize the arts along lines which would serve to glorify his image to his subjects and improve his prestige in the European political theater. In 1662, he wrote of the effects of this process, stating that, 'par là nous tenons leur esprit et leur coeur, quelquefois plus fortement peut-être, que par les récompenses et les bienfaits; et à l'égard des étrangers, dans un état qu'ils voient florissant d'ailleurs et bien reglé, ce qui se consume en ces dépenses qui peuvent passer pour superflues, fait sur eux une impression très avantageuse de magnificence, de puissance, de richesse et de grandeur, .... ${ }^{1}$ The standardization of the lavish entertainments at court assisted in this quest and further served to keep the nobility harmlessly occupied with non-political matters. Although no subsequent French monarch displayed a similar depth of understanding of the power of the performing arts, Louis XIV's systems and methods of organization were kept largely in place, thus forming the cornerstone of both court and public life during the eighteenth century. ${ }^{2}$ While the prestige of the monarchy remained linked with the performing arts during much of the reign of Louis $\mathrm{XV}$, significant changes began to manifest themselves during the reign of Louis XVI, with the result that the court no longer acted as the arbiter of public tastes.

When Louis XVI succeeded his grandfather to the throne of France in 1774 , he inherited a system of court entertainments and a resident body of musicians that had been lacking in direction for many years. Although changes in the administration of the musicians, introduced in 1761, had alleviated some of the worst problems, other problems remained. ${ }^{3}$ What was lacking was the external impetus necessary to encourage the royal musical establishment to rise above the level of routine and to make it once again sparkle as one the country's most illustrious cultural jewels. During the era of Louis XIV, this impetus came from the king himself, ably assisted by Jean-Baptiste Lully (1632-87) and, at a later time, by André-Cardinal Destouches (1672-1749). Louis XV was not musical and 
the musical activity at his court centred first around the queen, Marie Leczinska (1703-68), who was guided in her choices by the conservative Destouches and François Colin de Blamont (1690-1760) and, subsequently, around Mme de Pompadour (1721-64), following her ascendency in 1745 to the position of royal mistress. Economic problems plagued the country during the final years of this reign, and the court lost much of its luster prior to the death of Louis XV in 1774. It was generally hoped that the youthful Louis XVI and the spirited Marie Antoinette would rekindle some of this lost artistic splendor at court.

As a monarch, Louis XVI was well-intentioned, but lacked leadership ability. He seems to have known almost nothing about the organization and importance of the court's entertainments prior to his ascension to the throne. Indeed, when Papillon de la Ferté, surintendant of the MenusPlaisirs and the man responsible for the court's entertainments, came to pay his respects to the new king on 20 May 1774, Louis XVI greeted the astonished man with a blank stare and the statement that he had never heard of the Menus-Plaisirs and certainly had no need for them. ${ }^{4}$ Such ignorance was quickly remedied - even the composer Gluck assisted in the matter; ${ }^{5}$ however, Louis XVI's involvement with the performing arts rarely extended beyond an administrative interest which saw to the establishment of the Ecole Royale de Chant et de Déclamation (1784) and the awarding of prizes for opera libretti. If the court was to regain its former position of active leadership in the area of the performing arts, the direction would have to come from the new queen, a person who had already demonstrated considerable interest in music.

From an artistic standpoint, Marie Antoinette's reign as dauphine, and later queen, can be divided into two distinct periods of influence which roughly correspond with the decades of the 1770 s and the 1780s. She was brought from Austria to France in 1770 and married the dauphin on 16 May. This union, the final successful diplomatic action of the duc de Choiseul, was unpopular with the French public and, other than cementing the existing alliance with Austria, brought few political advantages with it. The amoral French court was unlike anything Marie Antoinette had previously experienced, and tensions soon mounted between herself and the king's current mistress, Mme du Barry. Indeed, after the fall of the duc de Choiseul, Marie Antoinette decided not to recognize Mme du Barry in any way. She remained firm in her resolve until New Year's Day, 1772, at which time a few words in passing were uttered to Mme du Barry in order to please her father-in-law. ${ }^{6}$ Such antagonism continued and resulted in a spirit of competition between the royal mistress and the dauphine, with the result that the final years of the reign of Louis $\mathrm{XV}$ were marked by artistic controversy, especially in the area of music. 
It has often been stated that Marie Antoinette's general education had been neglected by her mother Empress Maria Theresa of Austria, a point which Mme Campan, lady-in-waiting to the dauphine, may have overstated in her memoires. Certainly, Marie Antoinette had been raised in a cultural and aesthetic environment different from that of the French court. Given the fact that she had received music lessons from none other than Gluck in Vienna, Marie Antoinette could hardly have been ignorant of music, as claimed by Mme Campan. Her youth and lack of experience with French culture likely made her appear more uneducated than she actually was. ${ }^{7}$ Certainly, the young dauphine was capable of forming strong opinions about the music that she heard in France. Letters to her sister and mother from 1770 indicate her dislike of what she perceived as superficial qualities in French music. She wanted to promote her former music master, Gluck, but was afraid of too greatly praising the composer for fear of prejudicing the court against him. ${ }^{8}$ It would appear that, from the outset, Marie Antoinette hoped for significant changes in the musical traditions of the French court. Within a couple of years, she began to formulate the necessary plans to institute these changes, plans that were destined to bring her into open conflict with Mme du Barry.

Mme du Barry had no particular pretensions to artistic ability as had her predecesor, Mme de Pompadour. Du Barry was imperious and used the performing arts solely for her personal entertainment and to further her position at court. The records of both the Comédie-Française and the Comédie-Italienne demonstrate how the wilfull royal mistress often appropriated actors for private performances in her chambers when the companies were giving performances at court. Mme du Barry also loved to command performances of lavish musical and dramatic spectacles. Louis Petit de Bachaumont records one such lavish fête at Versailles in 1773 , in which approximately one hundred singers, dancers and actors took part. ${ }^{9}$ Such occasions were designed to further her prestige at court at the expense of her hated rival, the foreign-born Marie Antoinette.

During the period of $1773-74$, this rivalry came to a head as Marie Antoinette sought to introduce Gluck into the French musical scene. The composer had already been working at a French opera with the librettist F.-L. Du Roullet (a diplomat at the French embassy in Vienna), as attested by Charles Burney who heard excerpts of the new work during his trip to Vienna in $1770 .{ }^{10}$ Gluck appears to have realized that, following the death of Rameau in 1764 , there had been no native-born operatic composer who had been able to capture the hearts of the French public and heal the rift in the audience that had developed following the performance of Italian intermezzi in Paris. ${ }^{11}$ With his former royal student now the dauphine of France, Gluck must have believed that the odds of his success in Paris were in his favour, and thus began his assault upon 
the Académie Royale de Musique. ${ }^{12}$ This was initially carried out in the press of the day. Letters in the Mercure de France by Du Roullet (October 1772, II: 169-174) and Gluck (February, 1773: 182-84) sought to underscore the composer's desire to create an operatic art form that knew no national boundaries, while emphasizing his deep respect for the French dramatic traditions. ${ }^{13}$ When necessary, Gluck could be a skilfull diplomat and he was able to secure the support of leading members of the intelligentsia, including Rousseau, and of powerful people at court. His most powerful ally was the dauphine who, as the diarist Louis Petit de Bachaumont (14 January 1774) records, let it be known that the composer had permission to call upon her at any time. What Gluck could not have foreseen were the problems that Mme du Barry and her coterie would cause at court and the deplorable lack of discipline at the opera house itself.

Gluck found the management, singers and orchestra unresponsive and a full six months of rehearsals were undertaken before his Iphigénie en Aulide was ready for performance. Bachaumont (3 April 1774) records that, shortly before the premiere, Mme du Barry announced that she would bring the composer Niccolò Piccinni (1728-1800) from Italy as a rival to Gluck. Marie Antoinette was outraged and influenced Louis XV to prevent this from happening. Never before had the dauphine exerted such control over the court, and her prestige there now rested upon the successful presention of Gluck's first French opera. ${ }^{14}$ Finally, on 19 April 1774, all obstacles were overcome and Iphigénie en Aulide was performed in Paris. The power and breadth of Gluck's music was foreign to French audiences and the first performance met with a mixed reception. What applause was heard was largely attributed to the public's desire to please the dauphine. In a letter to her sister, dated 26 April 1774, Marie Antoinette states that the public and courtiers had taken strongly opposed sides over the opera and debated it as hotly as one might a religious matter. ${ }^{15}$ Subsequent performances were more warmly received and Bachaumont (27 August 1774) records that the queen awarded the composer a pension of 6,000 livres, with the promise of the payment of the same for each new operatic work. Gluck was well aware of the nature of his indebtedness to the dauphine and wrote to her, stating that 'honoured with your protection, it is to this advantage that I undoubtedly owe the applause I have received. ${ }^{16}$ As Stefan Zweig has noted, the opera was ultimately a triumph, but more for Marie Antoinette than for Gluck. ${ }^{17}$ It was now clear who would provide artistic leadership at court and whose model would be followed in Paris. Indeed, Gluck's opera was to remain closely associated with Marie Antoinette and the Mercure records that the queen was publicly 
acclaimed during performancs of this work on 13 January 1775 and 23 December $1778{ }^{18}$

Within four weeks of the premiere of Gluck's opera, Louis XV died and Marie Antoinette found herself Queen of France. Old factions within the court subsided with the dismissal of Mme du Barry. Once the period of mourning for Louis XV had been observed, life at court once again became fashionable and Versailles became the site of renewed artistic activity. One of Marie Antoinette's first artistic decisions was to provide the composer A.-E.-M. Grétry (1742-1813) a significant pension. Grétry had been trained in Rome and had longstanding connections with the Comédie-Italienne. The composer's Italianate tastes and philosophe sympathies made him a somewhat unusual choice for this honour; however, it was indicative of the winds of change that were sweeping through Versailles and, thereafter, Paris. ${ }^{19}$

At Versailles, court balls were re-introduced and the queen further proclaimed that performances by the Comédie-Française and the Comédie-Italienne should be presented at court on a weekly basis. ${ }^{20}$ Concessions to the poor state of the economy were made in the area of the performance of serious operas, the most expensive of the performing arts to mount, and it was ultimately decided that the court would visit the Académie Royale de Musique in Paris, rather than having its musicians perform at Versailles. These measures were greeted with enthusiasm by the courtiers, even though they remained suspicious of Marie Antoinette. As Madame Campan records, 'the courtiers did not fully enter into the popular enthusiasm which the Dauphiness had inspired; the disgrace of the Duc de Choiseul had removed her real support from her; and the party which had the ascendency at Court since the exile of that minister was, politically, as much opposed to her family as to herself. ${ }^{21}$ Thus, while the new queen maintained her popular support in Paris, she began her reign at court with a serious disadvantage.

Within two years, Marie Antoinette learned how fickle her popular support could be in Paris. Her earlier studies of music had provided her with insights into French musical tastes; however, she seems to have had few instincts for either literature or the visual arts of her adopted country. The queen was pursuaded to recommend the performance of a play entitled La Lecture interrompue (also known as Dramomame), written by the king's equerry, the chevalier de Cubières, during the voyage to Fontainebleau in 1776 . The strange plot in which all of the characters die from eating a poisoned pie, proved to be so offensive that Louis XVI ordered the performance on 30 October stopped before its conclusion. Both the author and the queen were humiliated by the experience, yet for the queen, the events of the following day eventually proved to be equally as embarrassing. On 31 October, the court wit- 
nessed the premiere of Chamfort's Mustapha et Zéangir. The play was a success and the queen's enthusiasm was such that she secured a lavish pension for Chamfort. This should have foretold of a great success when the work was presented in Paris; however, the play ultimately failed. As Madame Campan noted, 'the spirit of opposition which prevailed in that city delighted in reversing the verdicts of the Court. The Queen determined never again to give any marked countenance to new dramatic works. She reserved her patronage for musical composers, .....22 Such events were to become typical of the troubled second half of the reign; however, the years up to 1780 were marked by more positive experiences in the area of music.

The queen's patronage of Grétry did much to aid the reputation and fortunes of the Comédie-Italienne, which had suffered much during the late years of the previous reign, and the crown took an active interest in helping the company restructure and restore its financial base. In addition to the greater prestige afforded to the troupe by the queen's interest and frequent visits to its performances, her endorsement of Gluck paved the way for other foreign composers, many of them Italian, at the Académie Royale de Musique. One of the first new works to be performed was Les Horaces (21 January 1777) by the Viennese composer, Joseph Starzer. The following year (17 January 1778) witnessed the great success of Roland composed by Niccolò Piccinni. ${ }^{23}$ Prior to the Revolution, the works of Piccinni, Paisiello, Anfossi, Sacchini, Traetta, J.C. Bach, and Salieri formed a significant part of the repertory of the Académie Royale de Musique. ${ }^{24}$ Nor was opera the only area in which foreign-born musicians came to dominate. A review in the Mercure (September 1777: 162-3) of the Concert Spirituel given at the Tuilleries on 15 August 1777 lists works by Sacchini, Prati, Piccinni, and Allessandri. The introduction of so many foreign composers to the Parisian opera and concert stages was a radical departure from tradition. The results were decried by French nationalists while supported by the philosophes who favoured Italianate music. Paradoxically, even Gluck became a target of the philosophes, largely because of his connections with Marie Antoinette. The controversies between the progressive faction of the audience and the nationalists were slow to die and Adolphe Julien has documented those over the merits of Sacchini and Salieri following Gluck's return to Vienna in $1779 .{ }^{25}$ Indeed, the Académie was in a state of near crisis by the end of the 1770 s.

Complicating this explosive situation was the presence of a troupe of Italian comic opera singers singing in Italian, initially under the direction of Piccinni, at the Académie from 1778 until 1780. This situation served to further the heated debates over the relative merits of Italian and French music. ${ }^{26}$ Marie Antoinette was perceived to be firmly on the side 
of Italian music. Her decision to take singing lessons from Piccinni resulted in the proliferation of Italian music and Italian styles of singing in Paris. While this was harmless enough, her lavish patronage of the composer Antonio Sacchini put her into direct conflict with Papillon de la Ferté, following the latter's transfer from the direction of the court's entertainments to the leadership of the Académie Royale de Musique in $1780 .{ }^{27}$

The roots of the problems that manifested themselves during the decade of the 1780 s originated in the earliest days of the reign. Marie Antoinette never succeeded in completely winning over her distrustful courtiers, and certain aspects of her personality were strongly criticized. The rigid and complicated etiquette protocols of Versailles were an anathema to the young queen and Madame Campan records her desire to live at the Trianon palace, a place where no court was held and the queen could live like a 'private person. ${ }^{, 28}$ Her near total aversion to the ceremonial side of court life led her to avoid public appearances and to prefer the company of a few trusted friends. This, combined with her extravagance, a trait which manifested itself shortly after her arrival in France, fondness for private parties (an interest not shared by her husband), her preference of attending theatrical performances in Paris incognito, and her interest in harmless outdoor activities were all viewed as affronts to the dignity of the throne of France. She was criticized by the courtiers whose attitudes were soon adopted by the influential middle class of Paris. Complaints were raised of her capriciousness, and calumnies were spread concerning her morals. ${ }^{29}$ During the second half of the reign, Versailles was often a dull place indeed, and the courtiers spent far more time in Paris where the entertainments were more frequent and the social life more stimulating, than they did at Versailles. While this situation had a beneficial effect upon the popularity of public concerts in Paris and the frequency of musical performance in the private homes of the wealthy, the court's traditional role of artistic leader for the nation was seriously diminished. ${ }^{30}$ Indicative of this decline is Bachaumont's report (9 January 1786) that the large concert hall at Versailles was no longer used for court performances because it was too big and that a smaller one had been constructed to meet the needs of the court.

Further complicating this situation was a lack of consistency in the presentation of the court's entertainments. If the court was to maintain its role of being the arbiter of public tastes, it was important to demonstrate the interest of the monarchs in the area of the performing arts and to maintain an active artistic life at court. Louis XVI lacked both the inclination and the time for such activities and Marie Antoinette showed little desire to continue with the kind of musical leadership that she had previously demonstrated. The result was that both the scope and fre- 
quency of court entertainments diminished rapidly. Traditionally, the voyages to Fontainebleau were the most important artistic occasions for the court and times when premieres of new works were usually given. Yet, only three such voyages were undertaken between 1778 and the Revolution. ${ }^{31}$ The daily records of the Comédie-Italienne show that the company's visits to Versailles were erratic. In 1779, the company made twenty-two court appearances, followed by only seven in 1780 . Twentythree performances were given there in 1781, but only eleven performances were mounted there in $1782 .^{32}$ The records of the Comédie-Italienne indicate that, of the twenty-eight times that Marie Antoinette attended plays in that theater, all but two of the occasions were made incognito. ${ }^{33}$ It appears that Marie Antoinette enjoyed attending plays, but found it tiresome to play the role of queen herself for the public of France. While economic problems undeniably contributed to the fluctuation in court entertainments, the lack of recognition by either the king or queen of the role that the performing arts had traditionally played in the public's perception of the prestige and power of the crown was ultimately harmful.

Indeed, a political spirit had begun to manifest itself in the area of drama, to the distinct liability of the king. Although Beamarchais's Le Barbier de Séville had found favour with both court and public audiences, the author's revolutionary tendencies in Le Mariage de Figaro brought him into direct conflict with Louis XVI. The author was well aware of its political content and, even though the Comédie-Française had accepted the work for performance and it appeared that the censors, who were divided over the matter, might pass the script, Beaumarchais arranged a series of private readings throughout Paris in order to garner public support. The queen and her coterie found the new work to be amusing and wanted a court production of the play. This, however, required the king's approval and drew him into the affair. Mme Campan records that Louis XVI was so outraged by the play when it was finally read to him that he forbade all future performances, stating that Beaumarchais had mocked everything that must be respected in government. In an earlier time, the matter would have ended there. Beaumarchais and the comtesse de Polignac, a confidante of the queen, forced public opinion in their favor by distributing the parts of the play to the actors of Comédie-Française and then arranging for an open rehearsal on 13 June 1783. It is likely that Beaumarchais anticipated royal intervention, and the king's order to stop the performance was viewed by an already assembled audience as an affront to public liberty. The promise of revisions to the play resulted in the Comte de Vaudreuil, another close friend of the queen, securing permission to have the play performed at his private country estate. The play became so well known through 
manuscript copies in France that Catherine the Great of Russia offered Beaumarchais a premiere of the work in St. Petersburg. Humiliated, Louis XVI had little choice but to lift the ban upon the production of Le Mariage de Figaro, which was finally presented in Paris in 1784 . There was great popular support for the play and, although the king continued to be displeased, his advisors felt that it was best not to interfere further. ${ }^{34}$

Louis XVI was hurt in several ways by this matter. Beaumarchais had been politically useful during the early years of the reign and had helped to smooth over the scandal of the chevalier d'Eon. The king had retained real affection for Beaumarchais and was now very upset by his actions and those of the queen's coterie. Ultimately, Louis's willingness to be flexible in the matter was used against him for his detractors argued that, if he could be convinced to alter his opinion over a play, he might bend to the influence of Austria through his wife in a matter of state.

In spite of such unpleasant situations, the king and queen continued to provide financial support to writers such as Bernadin de Saint-Pierre during the decade of the $1780 \mathrm{~s} .{ }^{35}$ Indeed, the status of writers appears to have risen considerably, if the events of the voyage to Fontainebleau in 1786 can be taken as an indication. Grétry's opera, Le Comte d'Albert, was given its premiere at the chateau on 13 November. The work was not a success and the librettist, M.J. Sedaine, publicly accused Papillon de la Ferté of sabotaging the performance through excessive financial restraints in the production. Papillon de la Ferté's indignation over a mere author making such comments was effectively silenced by Marie Antoinette's statement that 'quand le roi et moi parlons à un homme de letttres, nous l'appelons toujours Monsieur' (Bachaumont, 22 November 1786).

Such gestures, however, did little to resuscitate the reputation of a queen who had became a veritable liability for the reign. Her virtual withdrawal from court life, her apparent lack of tact, her much-discussed extravagance, her love of gambling and diamonds, and the ever-present fear that she would influence her weak husband to the benefit of Austrian interests all served to arouse suspicion. The final blow was the scandal of the famed diamond necklace which dragged through the courts until 31 May 1786 and, in the process, discredited the queen's reputation. ${ }^{36}$ Although Marie Antoinette continued in her appreciation of music during this period and attempted to support her favorite composers, her efforts were regarded as the unwarranted intrusions of a foreigner at a time when a spirit of nationalism was growing. In particular, her patronage of Antonio Sacchini brought her into direct conflict with the powerful Papillon de la Ferté and served to add further fuel to the flames of operatic controversy in Paris. 
When Sacchini arrived in France in 1781, he had already composed more than forty operas and was known to the audiences of the ComédieItalienne through the performances of his La Colonie and L'Olimpiade. ${ }^{37}$ The queen was much taken with the composer and did all in her power to ensure his success in Paris. Through her support, Sacchini was offered the opportunity to compose an opera for the Académie. Since Sacchini had already composed an Italian opera, Armida (1772, rev. 1780), the decision was made to allow the composer to adapt his existing music to the libretto written by the Abbé Pellegrin for Desmarets's Renaude, ou la Suite d'Armide (1722). The libretto was to be updated by the little-known author Jean-Jospeh Leboeuf. The queen was much concerned that the selection of this author was an attempt by Papillon de la Ferté to undermine the success of Sacchini and interceded on behalf of the composer. At her suggestion, Leboeuf's work was examined by a committee on 17 June 1782. The demands for changes in Leboeuf's work and various intrigues at the Académie resulted in the delay in the production of Sacchini's Renaud until 28 February $1783 .{ }^{38}$ Ultimately, the work was not not well-received, and the queen's interference in the workings of the Académie was resented.

Operatic controversies continued to unfold in Paris as rival factions developed around Piccinni and Sacchini, whose works were now judged against the standards set earlier by Gluck. Indeed, in 1781, Piccinni was asked to compose an opera on the very same subject as Gluck's popular Iphigénie en Tauride so that the comparisons could be more obvious. The rivalry between Piccinni and Sacchini came to a head during the court's voyage to Fontainebleau during the fall of 1783 . Both composers were given the opportunity to present a new opera in the tragédie lyrique genre. Piccinni's Didon (given on 16 October) was an immediate success; however, much to the regret of the queen, Sacchini's Chimène ou Le Cid (a re-working of his earlier Italian opera, $\mathrm{Il} \mathrm{Cid)} \mathrm{did} \mathrm{not} \mathrm{please} \mathrm{the} \mathrm{court.}{ }^{39}$ Marie Antoinette's inability to influence the courtiers was obvious. Even more significant were the events that followed in Paris. The public of Paris saw matters differently and reversed the court's decision on Sacchini's new work when it was presented at the Académie. As the perceptive comte de Ségur was to note, 'en ce genre, comme en d'autres, Paris ne ratifia pas toujours les jugements de la cour. ${ }^{40}$ Such reversals had already been commented upon by the Englishman, John Moore, in 1779 when he wrote that 'obedient to the court in every other particular, the French disregard the decisions pronounced at Versailles in matters of taste. ${ }^{41}$ This unfortunate relationship between the court and public continued throughout the remaining years of the reign.

Indeed, the events of the court's next voyage to Fontainebleau (10 October-17 November, 1785) are indicative of this relationship. Bachau- 
mont ( 8 November 1785 ) notes that 'il y a une rivalté de goût absolument ouverte entre la cour \& la ville.' The antipathy seems to have been active on both sides for, at Fontainebleau in 1785, the courtiers rejected Grétry's Richard Coeur-de-Lion, a work which had long been popular in Paris. The premieres of Philidor's Thémistocle and Piccinni's Pénélope (13 October and 2 November 1785, respectively) were similarly not well received. This was a considerable surprise for those in charge of the Académie in Paris, especially with Pénélope, for which a great success had been predicted and a measure of which did materialize when the work was presented in Paris. Sacchini's Dardanus (composed to a revised version of the libretto originally set by Rameau in 1739) had not been a great success when it was presented in Paris in 1784, but was given a triumphant reception at Fontainebleau on 22 October 1785. Bachaumont (8 November) states that the composer was overjoyed at this reception and let it be known that he had composed this opera with court tastes in mind, rather than those of Paris. Such comments did little to enhance his reputation in Paris, but they are indicative of the artistic rift between the court and the general public.

Similar events marked the voyage to Fontainebleau in 1786 . The queen had promised Sacchini that the premiere of his opera Oedipe à Colone would be given during the voyage. The complaints concerning her patronage of a foreign composer were such that J.-B. Lemoine's Phèdre was substituted in its place. ${ }^{42}$ Marie Antoinette is recorded as having said to the disappointed Sacchini: 'Mon cher Sacchini, on dit que j'accorde trop de faveur aux étrangers. On m'a si vivement sollicitée de faire représenter, au lieu de votre Oedipe, la Phèdre de M. Lemoine, que je n'ai pu m'y refuser. Vous voyez ma position, pardonnez-moi. ${ }^{, 43}$ The death of Sacchini just prior to the voyage did nothing to make the queen's defeat in this matter less bitter and Bachaumont ( 31 October) records her particularly acrid comments following the premiere of Lemoine's opera on 26 October.

By the end of the reign of Louis XVI, the performing arts had lost most of their traditional functions within a court that was no longer the arbiter of public tastes, but had come to represent their antithesis. On the surface, it would appear that the reign of Louis XVI had but a brief influence over artistic matters in France, and that this influence was already muted before the final, desperate days of the reign. Paradoxically, the influence of this reign in the field of serious opera was very real and has been much underestimated in the documentation of this reign. Indeed, the results of this influence continued to be felt throughout the nineteenth century, both in France and in other European countries. 
French serious opera had been the creation of Jean-Baptiste Lully in the latter years of the seventeenth century. Although Italian by birth, Lully had been brought to Paris while still a teenager, and quickly absorbed French tastes and manners. As astute in manners of politics as he was in the field of music, Lully quickly rose to the top of Louis XIV's musicians and achieved a position of considerable power at court. As the director of the Académie Royale de Musique, Lully was able to chart the future course of opera in France, one based on the principles of classical French theater. As opposed to Italian opera of the same era, French serious opera did not cater to the famous castrati and their demands for vocal fireworks, called coloratura. In its place was a flexible system of recitative and air, tempered with dramatically-relevant choral singing and dance. This style of opera was significantly different from its Italian counterpart and it remained the only kind of serious opera that was performed in Paris until the Revolution. As Jean Mongrédien has noted, 'when the whole of Europe - from Lisbon to St Petersburg, from Vienna to London - was in the grip of Italian opera seria, France was still hermetically sealed against this foreign form of art. ${ }^{44}$ While it is true that Rameau's late operas began the process of breaking down such stylistic isolation, the great French composer remained true to many of the French musical traditions. Attempts at exporting the French style of opera were similarly stillborn. Niccolò Jommelli came close to reforming Italian opera seria along the lines of French opera during his fifteen years of service in Stuttgart (beginning in 1754) but, when his works were performed in Italy, audiences were not impressed ${ }^{45}$ The first successful attempt at a cross fertilization of these radically different styles of opera took place only after Gluck's success in Paris.

The lack of a French composer of true greatness during the late years of the eighteenth century resulted in the domination of the operatic stage in Paris by foreign composers, most of whom were Italian by birth or training. The music of composers such Sacchini, Salieri and Cherubini for Paris had to conform to French tastes and it differed in many ways from the music that they composed for performance outside of France. For Paris, these composers had to learn a restrained melodic style that was more declamatory in nature. Greater emphasis had to be given to the chorus, dance, scenic design and plot if the opera was to have any chance of success there. The results were a significant hybrid of Italianate musical aesthetics coupled to French dramatic principles.

Given that many of the visiting composers came to Paris with international reputations, it is not surprising that most of their French operas were then translated into Italian and played throughout the rest of Europe in that language. The influence of this new style of opera was profound. In Naples, the Italian impresario Domenico Barbaia (?1778- 
1841) introduced Italian versions of Spontini's La Vestale (1807) in 1811 and Gluck's Iphigénie en Aulide (1774) in 1812. ${ }^{46}$ Such was the success of these offerings that when, in 1813, Barbaia offered a contract to Johann Simon Mayr for a new opera on the Medea legend, it stipulated that the work should be composed in the French manner, which Barbaia suggested was the only appropriate model. ${ }^{47}$ Although Mayr's melodic idiom remained largely Italianate, his resulting opera, Medea in Corinto (1813), was notable for the inclusion of such French elements as the use of dramatic choruses, ensemble singing and accompanied recitatives. This style was new to Italian serious opera and it evoked much interest, the results of which can be seen in the serious operas of Rossini and Donizetti. ${ }^{48}$ Thus it was the French operatic style, as adapted by Italian composers in the late years of the eighteenth century, that served as the greatest impetus in the reform of traditional Italian opera seria and helped give birth to Italian romantic operas of the nineteenth century.

It is unlikely that this exchange of musical influences would have taken place when it did had not Marie Antoinette so actively supported foreign-born composers in the 1770s and 1780s, and popularized the works of Gluck and Sacchini. The opera houses in France opened up to foreign composers, never to close again. The results of this experience thus enriched the musical language of opera in both France and Italy alike. The breaking down of the stylistic isolation that had characterized French music and, in particular, French opera, since the seventeenth century was one of the most significant cultural developments during the late years of the eighteenth century. This was the lasting legacy of Marie Antoinette and the court of Louis XVI.

\section{PAUL F. RICE \\ Memorial University}

\section{Notes}

1 Mémoires de Louis XIV, publiés avec une introduction et des notes par Jean Longnon (Paris: Editions Jules Tallander, 1927), 123.

2 These ideas have been presented with exceptional clarity by Robert Isherwood in 'The Centralization of Music in the Reign of Louis XIV,' French Historical Studies 6, ii (Fall: 1969): 156-71; and Music in the Service of the King: France in the Seventeenth Century. Ithaca: Cornell University Press, 1973.

3 See John E. Morby, 'The Great Chapel-Chamber Controversy,' The Musical Quarterly, 58 (July, 1972): 383-97, for further details. 
4 Casimir Stryienski, The Eighteenth Century, trans. H.N. Dickinson, The National History of France, vol. 5 (London: 1923; reprint edition, New York: AMS Press, Inc., 1967), 213-14. Strangely, Papillon de la Ferté does not record this incident in his celebrated journal. This journal has been edited by Ernest Boysse as Journal de Papillon de la Ferté: Intendant et contrôleur de l'argenterie Menus-Plaisirs et affaires de la Chambre du Roi (1756-1780) (Paris: Paul Ollendorf, 1887).

5 Gluck wrote a letter to Louis XVI in which he describes how the Greek leaders of antiquity, the Medicis and Louis XIV had 'encouraged and supported the arts, they had a more important aim in view than that of providing further amusement and pleasure; they regarded that portion of human knowledge as one of the most precious links in the political chain; they knew that only the arts are capable of making men gentle without corrupting them and of rendering them prone to submission without debasing them.' The letter is reprinted in Hedwig and E.H. Mueller von Asow, editors, The Collected Correspondence and Papers of Cristoph Willibald Gluck trans. Stewart Thomson (London: Barrie and Rockliff, 1962), 46-47.

6 G.P. Gooch, Louis XV: The Monarchy in Decline (London: Longman, Green and Company Ltd., 1956), 235-39.

7 J.L.H. Campan, Memoirs of the Court of Marie Antoinette, Queen of France. 2 vols. (New York: Merril \& Baker Ltd., n.d.), I: 97. It is unlikely that Mme Campan intended to slur the intellectual reputation of her mistress; however, her comments have contributed to the popular image of Marie Antoinette as being frivolous and empty-headed. Stefan Zweig, in Marie Antoinette: The Portrait of an Average Woman, trans. Eden and Cedar Paul (New York: Viking Press, 1933), 65-6, goes so far as to say that 'in artistic matters, Marie Antoinette's aptitudes were mediocre; she had little knowledge of music, painting, or literature. Perhaps she had a certain amount of natural taste; but she was devoid of independent preferences, ... She trifled with music, as with all else.' The present study serves as a rebuttal to some of Zweig's comments.

8 Correspondance inédite de Marie Antoinette, publiés sur les documents originaux, ed. Le Comte Paul Vogt d'Hunolstein (Paris: E. Dentu, 1864), 17 (28 June 1770) and 20 (27 August 1770).

9 Details of the repertory of the Comédie-Italienne can be found in Charles Brenner, The Theatre Italien: Its Repertory, 1716-1793, University of California Publications in Modern Philology, No. LXIII (Berkeley and Los Angeles: University of California Press, 1961). That of the Comédie-Française has been investigated by H. Carrington Lancaster in 'The Comédie Française: 1701-1774; Plays, Actors, Spectators, Finances,' Transactions of the American Philosophical Society, XLI/iv (December, 1951): 593-849.

Louis Petit de Bachaumont, Mémoires secrets pour servir à l'histoire de la république des lettres en France, depuis M.DCC.LXII jusqu'â nos jours. 19 vols. (London: John Adamson, 1780; reprint ed., Westmead, England: Gregg International Publishers Ltd., 1970), VII: 153. Subsequent references to this source will be by date of entry only.

10 Robert M. Isherwood, 'The Third War of the Musical Enlightenment,' Studies in Eighteenth-Century Culture. IV, ed. Harold E. Pagliaro (1975), 230.

11 This controversy, known as the guerre des bouffons, lasted from August of 1752 until March of 1754, with the effects of the dispute felt many years thereafter. The opera-going audience was deeply divided over the relative merits of Italian and French opera and their polemics spilled into the journals and newspapers of the day. Discussion of this colorful episode in French operatic history may be found in Cuthbert M. Girdlestone, Jean-Philippe Rameau: His Life and Work, rev. ed. (New 
York: Dover Publications, Inc., 1969), 500-06, and in Alfred Richard Oliver, The Encyclopediests as Critics of Music (New York: Columbia University Press, 1947; reprint edition, New York: AMS Press Inc., 1966), 89-100.

12 This process is discussed in some detail by Alfred Einstein, Gluck, trans. Eric Blom (London: J.M. Dent \& Sons, 1936; reprint edition New York: Collier Books, 1962), 149-59.

13 These letters appear in translation in Oliver Strunk, Source Readings in Music History. New York: W.W. Norton \& Co., 1950, 676-83.

14 The original date for the premiere of the opera was 13 April 1774. On the day of the performance, one of the leading singers took ill and Gluck refused to allow the performance to be given with an understudy. This all happened so late that Marie Antoinette had to countermand the order for the royal carriages. Both the dauphine and composer realized that far too much rested upon this premiere to allow its success to be undermined by an inferior singer.

15 Correspondance inédite de Marie Antoinette, 60-62. See also the letter LXXX (from May 1774) in the Correspondance inédite de Condorcet et Mme Suard, M. Suard et Garat (1771-1791), ed. Elizabeth Badinter (Paris: Librairie Fayard, 1988), 129-30, for evidence of this furor.

16 Gluck to Marie Antoinette in a letter written before 2 August 1774. Hedwig and E.H. Mueller von Asow, eds., Collected Correspondence, 48.

17 Zweig, Marie Antoinette, 67.

18 Mercure, February 1775, p. 121 and 5 January 1779, p. 51. Each time it was the text in Act II 'Chantons, célébrons nôtre Reine,' that stirred public sentiment. On the earlier occasion, the singers directed the lines of text directly to the royal box. On the subsequent occasion, the recent birth of the Queen's first child appears to have been the stimulus.

19 Grétry's star was clearly on the ascendancy and the Mercure (June $91775: 179$ ) reviewed a performance of his Céphale et Procris given at Versailles on 2 May 1775 with the following. 'Pour ses airs de ballet, on avouera sans peine que depuis Rameau on n'a rien entendu de mieux dessiné, de plus varié, de plus animé, de plus favorable à la danse.'

20 The court balls of the period of 1775-78 are described in some detail by Imbert de Saint-Amand, La Court de Marie-Antoinette (Paris: 1887), 157-65. Those which celebrated the marriage of the princesse Clotilde (sister of Louis XVI) to the prince de Piémont in August of 1775 were particularly memorable.

21 J.L.H. Campan, Memoirs of the Court of Marie Antoinette, Queen of France. I: 125.

22 Ibid., I: 204.

23 Marie Antoinette's enthusiasm for Piccinni was never as strong as it was for Gluck and, at a latter time, Sacchini. Although she had rejected the composer in 1774, she was forced to be more hospitable in 1777 because Piccinni's visit was sponsored by Queen Maria Carolina of Naples, sister of Marie Antoinette. The Gluck-Piccinni debates are discussed by Claude Manceron, trans. Patricia Wolf, Twilight of the Old Order 1774-1778 (New York: Alfred A. Knopf, 1977): 423-7, and Robert Isherwood, 'The Third War of the Musical Enlightenment,' (previously cited), 223-46. A study of greater depth, although rather dated, is offered by Gustave Desnoiresterres, Gluck et Piccinni: 1774-1800 (Paris: 1872; reprint edition, Geneva: Slatkine Reprints, 1971). 
24 An overview of the relative merits of some of these composers can be found in The New Oxford History of Music, vol. VII, The Age of Enlightenment: 1745-1790, s.v. 'Opera in France,' by Martin Cooper.

25 Adolphe Julien, La Cour et L'Opéra sous Louis XVI: Marie-Antoinette et Sacchini, Salieri, Favart et Gluck (Paris: 1878; reprint ed. Geneva: Slatkine Reprints, 1976). See also M. Elizabeth C. Bartlet, 'A musician's view of the French baroque after the advent of Gluck: Grétry's Les trois âges de l'opéra and its context,' Jean-Baptise Lully and the music of the French baroque: essays in honor of James R. Anthony, ed. John Hajdu Heyer (Cambridge: Cambridge University Press, 1989), 291-318. Typical of this musical controversy is the exchange of letters between the prince Beloselki, Marmontel and la Harpe found in the August and September issues of the Mercure of 1778.

26 Piccinni directed this troupe of Italian singers during 1778-79. The company's repertory consisted of the works of Anfossi, Paisiello, Sacchini, Traetta and Piccinni himself. The complete repertory of the Académie Royale de Musique can be found in Théodore de Lajarte, ed., Bibliothèque musicale de thêâtre de l'Opéra: catalogue historique, chronologique, anecdotique. 2 vols. (Paris: 1878; reprint, Hildesheim: Georg Olms Verlag, 1969).

27 Julien, La Cour et L'Opéra, 28.

28 Campan, Memoirs, I: 268-70.

29 Papillon de la Ferté makes many references to the queen's lack of fiscal restraint. The reader is directed to entries for 12 December 1773, 7 August and 13 October 1775, and 31 August 1777.

30 Jean Mongrédien provides an overview of the public and private concerts in 'Paris: the End of the Ancien Régime,' The Classical Era: from the 1740s to the end of the 18th century, ed. Neal Zaslaw (Englewood Cliffs, New Jersey: Prentice Hall Inc., 1989), 61-98.

31 For details of these voyages, see the present author's The Performing Arts at Fontainebleau from 1661 until 1786 (Ann Arbor, Michigan: UMI Research Press, 1989).

32 The dates of these performances are given in Charles Brenner, The Theatre Italien.

33 Ibid., 33. The queen's presence in the theater (certainly known to the actors and likely to many of the audience) soon ceased to be a novelty.

34 Georges Lemaitre, Beaumarchais, (New York: Alfred A. Knopf, 1949), 139-208.

35 John Lough, An Introduction to Eighteenth Century France, (London: Longmans, Green and Co. Ltd., 1960), 259.

36 The story of the diamond necklace has been reported in many sources. Mme Campan devotes many pages to her discussion of this intrigue. See Campan, Memoirs, II: 316-42.

37 Bachaumont (11 September 1786) preserves an amusing account of Sacchini's introduction to French opera.

38 Julien, La Cour et l'Opéra, 23-6.

39 Julien, 62, is incorrect when he states that Didon was presented on 16 November. This error has been carried over into The New Grove Dictionary of Music and Musicians s.v. 'Sacchini, Antonio' by David di Chiera. Both authors make the claim that Chimène was presented but once at Fontainebleau, as a result of the king's expressed command to view a third performance of Didon. This must be viewed with suspicion, especially since Ballard's printing of the Recueil des 
spectacles donnés devant leurs Majestés, à Fontainebleau, en l'année 1783 lists the second performance of Chimène on 20 November. Since this source was printed following the conclusion of the voyage, it should be viewed as accurate.

40 Cited by Julien, La Cour et l'Opéra, 64 .

41 John Moore, A View of Society and Manners in France, Switzerland and Germany, 2 vols. (London: 1779); cited by John Lough, An Introduction to Eighteenth Century France, 278.

42 Bachaumont (8 November 1785) speaks of the resentment by other composers for Sacchini's royal support and protection. The same author (29 October 1786) speaks of the humiliation that French composers experienced because of Sacchini's favored position. Jean-François Le Sueur must be excepted from this generalization, for he owed his appointment as choirmaster to Notre Dame in Paris, in part, to the support of Marie Antoinette.

43 Julien, La Cour et l'Opéra, 103.

44 Montgrédien, The Classical Era, 85.

45 See: Marita P. McClymonds, Niccolò Jommelli: The Last Years, 1769-1774. (Ann Arbor, MI: UMI Research Press, 1980): 9-12.

46 The New Grove Dictionary of Music and Musicians, s.v. 'Barbaia, Domenico' by Julian Budden.

47 The results can be heard today in the recording of Mayr's Medea in Corinto, Vanguard VCS-10087/8/9.

48 William Ashbrook, Donizetti and his Operas, (Cambridge: Cambridge University Press, 1982), 214. 